\author{
E. Gribanova ${ }^{1}$, V. Miamin ${ }^{1,2, *}$ \\ ${ }^{1}$ Belarusian State University, Minsk, 220108, Belarus \\ ${ }^{2}$ SNPO "SPC of the National Academy of Sciences of Belarus for Bioresources", \\ Minsk, 220072, Belarus \\ *Corresponding author: vladmiamin@mail.ru

\section{Physiological and biochemical traits of yeasts from soils of various ecosystems of East Antarctica}

\begin{abstract}
The diversity of psychrophilic / psychrotolerant microorganisms from Antarctica is a preferred subject of study by microbiologists, in turn, the communities of endolithic and hypolithic yeast cultures are practically not studied, and the literature on the biotechnological potential of such microorganisms should cover important biomolecules in addition to cold-adapted enzymes. In order to study the characteristics and biopotential of yeast cultures isolated from soil samples of East Antarctica, a number of physiological and biochemical tests were carried out. This article provides a list of the studied morphological characteristics, and also describes the results of the study of enzymatic activities and biochemical properties. In the course of research, it was revealed that Antarctic yeast isolates have a wide range of enzymatic activities when growing on agar media: most isolates were characterized by the presence of lipolytic, amylolytic, DNase, urease activities and the production of esters; a much smaller number of isolates were capable of manifesting proteolytic, cellulolytic and pectolytic activities, the release of organic acids and the formation of starch-like compounds. The study of tolerance to stress showed the presence of resistance of the studied cultures to the effects of ultraviolet radiation with a wavelength of $254 \mathrm{~nm}$ and low concentrations of copper sulfate in the environment. A qualitative assessment of the level of glycogen in yeast cells by staining with Lugol's solution showed that one culture is capable of accumulating glycogen in significant amounts. Additionally, the ability of yeast cells to accumulate lipids with increasing age of cultures was shown. The destruction of the surface of the mineral motor oil by the culture broth made it possible to identify yeast isolates with high destructive activity. This experience allows us to consider Antarctic yeast cultures as promising producers of biologically active compounds. The variety and spectrum of physiological activities of the investigated isolates allows us to consider them as promising producers of biological compounds for use in medicine and biotechnology.
\end{abstract}

Keywords: Antarctica, biosurfactants, enzymatic activities, microorganisms, stress tolerance

\section{Introduction}

Yeasts comprise a highly diverse group of eukaryotic microorganisms which differ in nutritional requirements and survive in harsh environmental conditions. They are found in saline and polluted waters, in soils containing different levels of heavy metals; they endure low humidity, high and low temperatures, UV radiation etc. (Satyanarayana \& Kunze, 2009). Turkiewicz et al. (2003) suggested that yeasts may be better adapted to low temperatures than bacteria. Therefore, it is not surprising that yeasts be- longing to genera such as Bullera, Candida, Cryptococcus, Cystofilobasidium, Debaryomyces, Kondoa, Leucosporidium, Metschnikowia, Mrakia, Pseudozyma, Rhodotorula, Sakaguchia, Sporopachydermia, Sympodiomyces and Trichosporon were identified in different habitats in Antarctica (Di Menna, 1960; Vishniac \& Hempfling, 1979).

The first article describing isolation of microorganisms from the snow samples collected in the Antarctic which is considered the coldest and driest habitat on Earth was published in 1941 (Darling \& Siple, 1941). Afterwards, there appeared many papers on microor- 
ganisms from various environments in Antarctica, mostly about isolation of cyanobacteria and actinobacteria (Cary et al., 2010; de Pascale et al., 2012; Gugliandolo et al., 2016). Despite the lately growing amount of research concentrating on the yeasts of the continent, our knowledge of them is yet limited and scarce.

Under low temperatures yeasts and bacteria contribute the most to the nutrients' recirculation and mineralization of organic matter (Gerday et al., 2000), having adapted their vital cellular processes to the low temperatures (D'Amico et al., 2006). Psychrotolerant yeasts have an optimum temperature for growth at about $15^{\circ} \mathrm{C}$ or lower, a maximum up to $25^{\circ} \mathrm{C}$ but are still capable of growing at $0{ }^{\circ} \mathrm{C}$ or below; in contrast, the psychrophilic microorganisms are capable of growing at $5^{\circ} \mathrm{C}$ and below, regardless of whether the optimum temperature was about $15^{\circ} \mathrm{C}$ or more (Gounot, 1986; Robinson, 2001). Low temperatures and limited access to nutrients in the Antarctica are serious problems for living organisms. To be able to use and compete for the carbon sources in their habitats, the yeasts which have adapted to secrete cold hydrolytic enzymes (Alcaíno et al., 2015) and antimicrobial compounds (Barahona et al., 2016), making them a promising array to screen for biotechnologically promising species.

Although the first report on the physiological and biochemical properties of Antarctic yeasts was published 55 years ago (Di Menna, 1966), the current publications are mostly dedicated to cold-tolerant bacteriae and archaea. There are comparatively few publications on the biodiversity and biotechnological application of the yeasts. Moreover, about $43 \%$ of isolates obtained by Connell et al. (2010) belonged to nondescript species, reflecting the lack of knowledge on the cultivable yeast biodiversity in various Antarctic biotopes (Sampaio, 1999).

Our work aimed at studying the physiology and biochemistry of cultivable yeasts isolated from different ecosystems of the East Antarctica.

\section{Materials and methods}

\section{Sampling design}

The study used eight samples of fine earths (hypoliths and endoliths) from the East Antarctica (Molodezhnaya Station in Enderby Land, seasonal base Gora Vechernyaya, and Prince Charles Mountains (MacRobertson Land)). The samples were collected from the wild in 2015-2017 (Table 1) (Gribanova \& Myamin, 2019).

\section{Enrichment cultures from soil samples}

Soil samples were mixed with $0.8 \% \mathrm{NaCl}$ at $1: 9$ ratio and incubated for four hours using a rotary shaker. After that, $0.1 \mathrm{ml}$ of the suspension was plated on the following media: Hata, Bold's Basal Media, Sabouraud dextrose agar, glucose peptone agar, Ashby's agar, HutchinsonClayton agar, with added antibiotics (chloramphenicol $(\mathrm{Cm})$ and streptomycin $(\mathrm{Sm}))$ to prevent bacterial growth. The Petri dishes were incubated at 10 and $18^{\circ} \mathrm{C}$ for four to five weeks (Zenova et al., 2002).

Table 1. Sampling metadata

\begin{tabular}{|c|c|c|c|}
\hline Sample & Collection site in E Antarctica & Hypoliths / endoliths & Collection year \\
\hline 1 & Molodezhnaya Station & hypoliths & 2016 \\
2 & Molodezhnaya Station & endoliths & 2016 \\
3 & Prince Charles Mountains & hypoliths & 2015 \\
4 & field base Gora Vechernyaya & hypoliths & 2015 \\
6 & field base Gora Vechernyaya & hypoliths & 2015 \\
7 & field base Gora Vechernyaya & hypoliths & 2017 \\
\end{tabular}




\section{Cryoconservation of pure yeast cultures}

In a plastic Eppendord tube there were mixed $200 \mu \mathrm{l}$ $20 \%$ glycerol and $800 \mu$ l of yeast culture washout with PBS medium from the surface of the agar medium. The tubes were stored at $-70^{\circ} \mathrm{C}$. A fortnight later, the cultures’ viability was tested (Babyeva \& Golubev, 1979).

\section{Capsule staining}

Capsules were visualized using two methods: the negative ink staining and staining using a Burri-Gins method. The preparations were viewed using a 100× magnification of light microscopy with immersion (Babyeva \& Golubev, 1979).

\section{Determination of the temperature optimum}

Yeast cultures were streak-plated on the Sabouraud dextrose agar and incubated at $4{ }^{\circ} \mathrm{C}, 10{ }^{\circ} \mathrm{C}, 18{ }^{\circ} \mathrm{C}$, $22^{\circ} \mathrm{C}, 28^{\circ} \mathrm{C}$ and $37^{\circ} \mathrm{C}$ for ten days with daily counts, after which the optimum temperatures for the studied cultures were inferred (Babyeva \& Golubev, 1979).

\section{Determination of the enzyme activities} of the isolated yeast cultures

\section{a) Amylolytic enzymatic activity}

To determine the amylolytic enzymatic activity, the yeast cultures were replica-plated on a Petri dish with a medium containing starch. The plates were incubated at 4 to $37^{\circ} \mathrm{C}$ for five days to study the difference in the manifestation of enzymatic activity at different temperatures of cultivation of Antarctic yeast cultures. Then, the plates were poured with the Lugol solution to visualize the results; for the isolates with amylolytic activity, there were seen clear zones around the colonies (Lysak \& Zheldakova, 2002).

\section{b) Lipolytic Activity}

The yeast cutures were replica-plated on a Petri dish with a medium containing Tween 20 or Tween 80. The Petri dishes were incubated at 4 to $37^{\circ} \mathrm{C}$ during five days. The positive result was the formation of opaque zones of various morphology around the yeast colony (Kurzanov, 1975).

c) Proteolytic Activity
The isolates were replica-plated on a Petri dish with the Calcium Caseinate Agar. The plates were incubated at 4 to $37^{\circ} \mathrm{C}$ for five days. The positive result was registered if lighter zones appeared around yeast colonies (Lysak \& Zheldakova, 2002).

d) DNAse activity

The isolates were replica-plated on a Petri dish with the DNAse Test Agar with Toluidine Blue and incubated at 4 to $37^{\circ} \mathrm{C}$ for five days. The positive result was registered if lighter zones appeared around yeast colonies (Karpov, 1985).

e) Cellulolytic Activity

The isolates were replica-plated on a Petri dish with a medium containing $2 \%$ carboxymethylcellulose solution. As a control we used a culture of Pectobacterium carotovorum 3-2. The plates were incubated at 4 to $37^{\circ} \mathrm{C}$ for two-five days, then poured with $0.1 \%$ Congo red for $15 \mathrm{~min}$ and washed with $8 \% \mathrm{NaCl}$. The positive result was registered if lighter or transparent zones appeared around yeast colonies (Zubov \& Tolchenov, 2012).

f) Pectolytic Activity

The isolates were replica-plated on a Petri dish with a medium containing $3 \mathrm{ml} 1 \mathrm{M} \mathrm{CaCl}_{2}$ and coated with $1 \%$ sodium polypectate solution. For the control we used a culture of Pectobacterium carotovorum 3-2. The plates were incubated 4 to $37^{\circ} \mathrm{C}$ for five days. The positive result was the formation of holes around the yeast colonies (Rukhlyadeva \& Korchagina, 1973).

g) Urease activity was tested in two ways:

- Rapid Urea Broth Test for Yeasts

To each Eppendorf tube we added $0.5 \mathrm{ml}$ of the Urea broth medium. Yeast cultures were added to the test tubes, and one test tube with only the test medium was left as a control for comparison. For inoculate, we used fresh cultures grown 5 days on the Sabouraud agar. The urease activity test was done at $37{ }^{\circ} \mathrm{C}$ during four to five days. For more robustness, we also did it at the same time at $18^{\circ} \mathrm{C}, 22^{\circ} \mathrm{C}$ and $28^{\circ} \mathrm{C}$. The results were read daily. Any change in color from the straw-colored to pink indicated that the tested cultures had urease (Roberts et al., 1978).

- Christensen Urea Agar Method

The medium was heated in a water bath to melt the agar and poured into test tubes $(4.5 \mathrm{ml}$ with $0.5 \mathrm{ml}$ 
$20 \%$ urea), mixed, and slanted. The yeasts were streaked on, with an uninoculated test tube as control. The cultivation lasted for up to five days, at the temperature optimal for the organisms. In ureasepositive cases the alkalinized medium changed the color to pink, in the negative, it remained yellow (Babyeva \& Golubev, 1979).

\section{Organic acids formation}

Molten chalk agar was poured into Petri dishes. The dried dishes were streaked with the tested isolates. They were incubated for $10-15$ days at $18^{\circ} \mathrm{C}$. In positive cases, there appeared transparent zones around the streaks (Babyeva \& Golubev, 1979).

\section{Ester formation}

$1 \mathrm{ml}$ of the liquid medium containing $1 \%$ yeast autolysate solution and 5\% glucose was poured into Eppendorf tubes. Every tube was inoculated with a yeast culture using a bacteriological loop. For the control, we used an Eppendorf tube with $1 \mathrm{ml}$ medium. The tubes were kept at $18{ }^{\circ} \mathrm{C}$ for two-five days. The esters were determined by odor (Babyeva \& Golubev, 1979).

\section{Starch-like compounds' production}

The cultures were streaked onto the medium for determining the formation of starch-like compounds medium and cultivated for $10-12$ days at $18{ }^{\circ} \mathrm{C}$. The dishes were poured with Lugol solution and left in the light for two hours. If starch-like compounds were present, the medium and (or) the colony were stained black (Babyeva \& Golubev, 1979).

\section{Growth in liquid media}

$5 \mathrm{ml}$ of the glucose-peptone medium with yeast extract was poured into sterile test tubes. The prepared test tubes were inoculated with the tested cultures and kept at $18^{\circ} \mathrm{C}$ for four weeks. The cultures' growth was analyzed (Babyeva \& Golubev, 1979).

\section{Tolerance to heavy metals $\left(\mathrm{CuSO}_{4}\right)$}

Petri dishes were poured with melted Sabouraud medium with $0.01 \%, 0.025 \%, 0.05 \%, 0.1 \%, 0.2 \%$, or
$0.3 \% \mathrm{CuSO}_{4}$. The yeasts were streaked onto the medium and kept at room temperature for five days with daily evaluation of the cultures' growth. The data were interpreted to infer the heavy metals' effect on the tested yeasts' growth (Bagaeva et al., 2013).

\section{Qualitative estimate of glycogen levels in the cells}

The cultures were streaked onto the YPD medium and incubated at $18^{\circ} \mathrm{C}$ for four weeks. The living cultures were stained with the Lugol solution. After twothree minutes the yeast cells were stained yellow and the glycogen, brown (Byrtusová et al., 2020).

\section{UV tolerance}

The cultures were irradiated with UV light $(254 \mathrm{~nm}$ wavelength) with the lamp $15 \mathrm{~cm}$ above the Petri dish for 5-55 min with a $5 \mathrm{~min}$ step. Afterwards the dishes were kept at $18{ }^{\circ} \mathrm{C}$ for 15 days. For the control we used the mesophilic cultures of yeasts Hansenula sp. and Rhodotorula mucilaginosa. UV tolerance was graded by colony formation (Villarreal et al., 2016).

\section{Biosurfactant production}

Cultures grown on the YPD medium were transferred to test tubes with $1 \mathrm{ml}$ of sterile distilled water. The suspensions were thoroughly vortexed. Then, $0.3 \mathrm{ml}$ cell suspension was transferred to a test tube with $5.7 \mathrm{ml}$ liquid culture medium (BPM). The cultures were kept at $18^{\circ} \mathrm{C}$ for five days on a rotary shaker. Afterwards they were centrifuged for $20 \mathrm{~min}$ at $10.000 \mathrm{rpm}$. The supernatant was used to calculate the emulsification index (EI).

To determine the EI, we mixed $4 \mathrm{ml}$ supernatant with $4 \mathrm{ml}$ kerosene and actively mixed for $2 \mathrm{~min}$. The EI was calculated by the formula:

$$
\mathrm{EI}=(\text { foam height } / \text { total column height }) \cdot 100 \%
$$

The rest of the culture broth was used for the wetting test and the drop collapse test (Fedorova et al., 2010; Bueno et al., 2019).

\section{Wetting test}

A drop of yeast suspension cultured on the BPM was placed upon a paraffinized glass slide. For the control 
we used a drop of distilled water and measured its diameter. The larger the difference between the tested culture's diameter compared to the water drop's diameter, the higher the wetting activity of the suspension (Fedorova et al., 2010; Bueno et al., 2019).

\section{Drop Collapse test}

To a sterile Eppendorf tube we added $150 \mu \mathrm{l}$ mineral motor oil and left for an hour, after which we added $200 \mu \mathrm{l}$ of a a culture's supernatant. The results (the change in the oil volume) were read after $1 \mathrm{~min}$, after

Table 2. Morphological features of the colonies in pure yeast cultures

\begin{tabular}{|c|c|c|}
\hline Sample & Culture & Traits of the colony \\
\hline \multirow[t]{5}{*}{1} & 15 & $\begin{array}{l}\text { White to transparent, matte, flat, uneven } \\
\text { edge }\end{array}$ \\
\hline & 32 & $\begin{array}{l}\text { White to transparent, matte, flat, uneven } \\
\text { edge }\end{array}$ \\
\hline & 16.1 & White, round, convex, glossy \\
\hline & 16.2 & White, round, convex, glossy \\
\hline & T3-1 & Beige, round, convex, glossy \\
\hline \multirow[t]{2}{*}{2} & 2 & White, round, convex, glossy \\
\hline & 3 & Transparent, round, convex, glossy \\
\hline \multirow[t]{3}{*}{3} & 38 & Pink, round, convex, glossy \\
\hline & 39 & White, round, convex, glossy \\
\hline & 26 & Light pink, round, convex, glossy \\
\hline \multirow[t]{7}{*}{4} & 1 & Coral, round, convex, glossy \\
\hline & 6 & Orange, round, convex, glossy \\
\hline & 7 & Creamy, round, convex, glossy \\
\hline & 8 & Orange, round, convex, glossy \\
\hline & 9 & Pink, round, convex, glossy \\
\hline & 10 & $\begin{array}{l}\text { Creamy with a white circle inside, } \\
\text { convex, glossy }\end{array}$ \\
\hline & 11 & $\begin{array}{l}\text { Creamy without a circle inside, convex, } \\
\text { glossy }\end{array}$ \\
\hline \multirow[t]{2}{*}{7} & 71 & Red, round, convex, matte \\
\hline & 180 & Light pink, round, convex, matte \\
\hline 8 & 36 & Creamy, convex, edge, glossy \\
\hline
\end{tabular}

Note: the name of the studied cultures included the number of the sample from which the culture was isolated and the number of the isolate. For example, culture "15" was isolated from soil sample № 1, so the culture was designated as "1-15". Also with the rest of the isolates.
3 min, after 1 hour and 1 day (Fedorova et al., 2010; Bueno et al., 2019).

\section{Results}

Six samples yielded 20 yeast isolates total when grown on different media. The colonies differed in color (orange, pink, red, creamy, white) and in morphology (Table 2). The obtained isolates were stored at $-70^{\circ} \mathrm{C}$.

The isolates were identified as yeasts based on the morphology and size of cells using a $100 \times$ magnification of a light microscope. They are currently being identified by molecular-biological methods.

We studied the isolates' physiological and biochemical features.

Most yeasts' optimum growth temperatures were between 10 and $22^{\circ} \mathrm{C}$, with no strictly psychrophilic isolates found. Therefore, growth studies at negative temperatures were not carried out.

Cell tolerance to various environmental impacts can be provided by various mechanisms, for example, by encapsulation. This was confirmed by negative staining with ink and staining after Burri-Gins techniques: all isolates produced capsules (Fig. 1). Examples of results correspond to $100 \times$ magnification of a light microscope.

The isolates' responses to stress shed light on their adaptation abilities. One of them is tolerance to a range of concentrations of some heavy metal in the medium (in our case, $\mathrm{CuSO}_{4}$ at 0.01 to $0.3 \%$ ), yet we did not find the high tolerance we expected of the isolates. All cultures grew robustly at $\mathrm{CuSO}_{4}$ levels up to $0.05 \%$ (Fig. 2). This figure shows the qualitative results of studies of cultures 7-71 (red), 7-180 (light pink) and 8-36 (creamy) as an example.

The isolates were also put under the UV light for some amount of time (5-55 min) after which the cells' viability was checked. Nine isolates had high UV tolerance (were viable after 40 min of irradiation) (Gribanova \& Miamin, 2021a).

A study of the enzymatic activities of the antarctic yeasts revealed the lipolytic, amylolytic, DNAse, and urease activities for most of them. A far fewer number of isolates was capable of proteolytic, cellulolytic, and pectolytic activities. Most isolates produced esters, some were able to secrete organic acids and make 


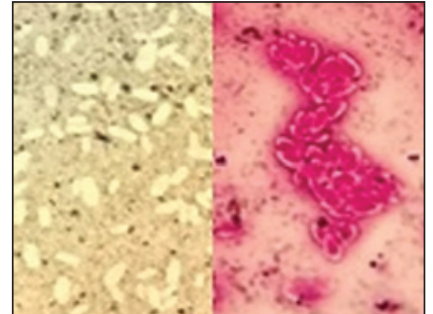

1-16.2

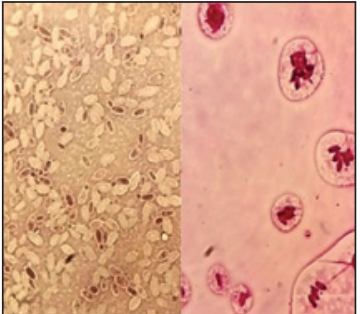

7-71

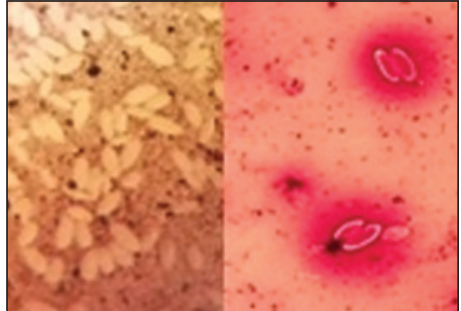

4-1

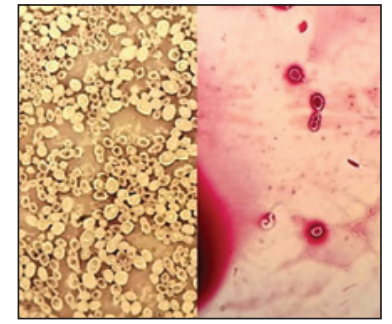

8-36

Figure 1. Examples of staining results for the tested cultures by the negative staining with ink (left) and Burri-Gins (right) techniques for each represented culture

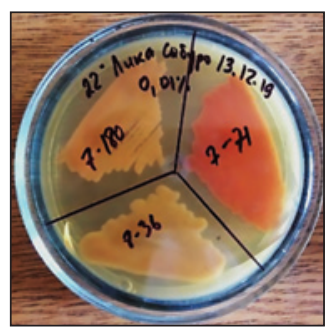

$0.01 \%$

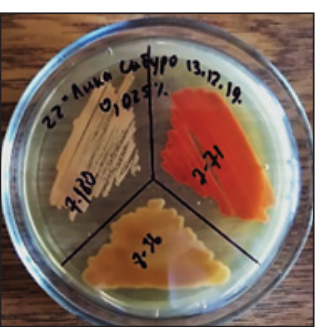

$0.025 \%$

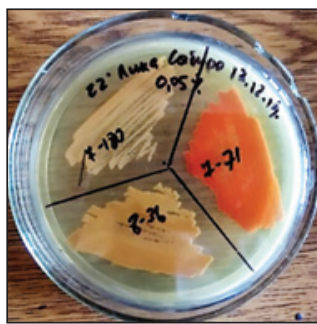

$0.05 \%$

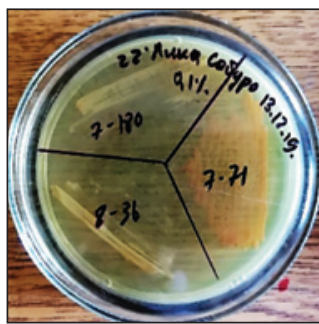

$0.1 \%$

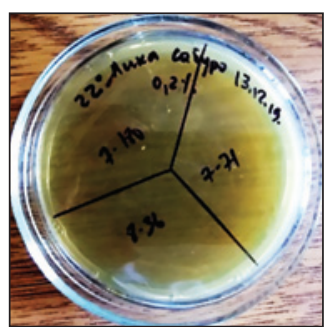

$0.3 \%$

Figure 2. Differences in the stability of growth of yeast cultures at different content of $\mathrm{CuSO}_{4}$ in the nutrient medium

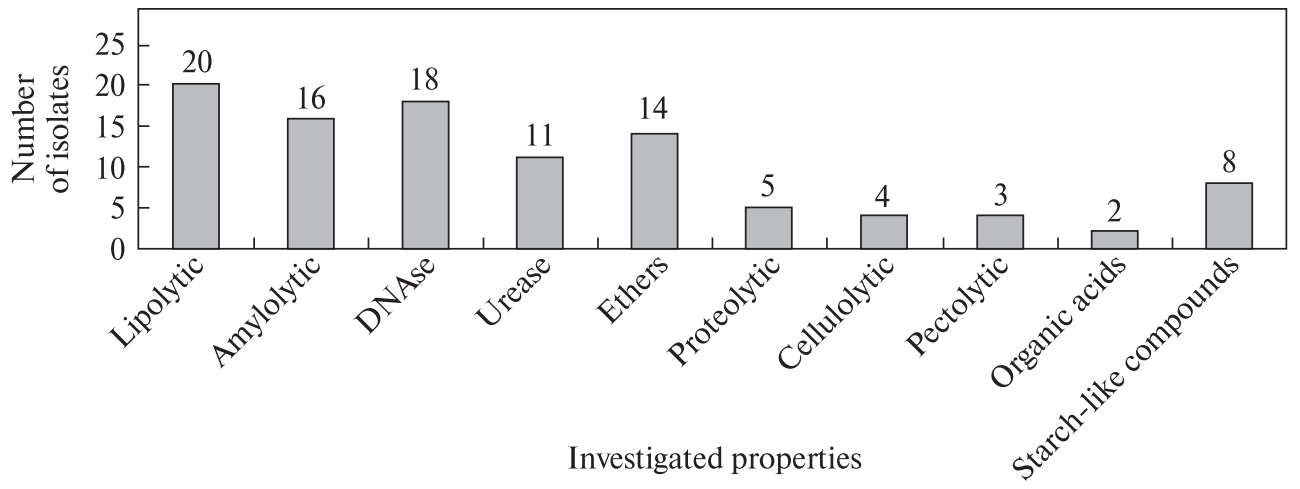

Figure 3. Enzymatic activities in yeast isolates

starch-like compounds (Fig. 3, Table 3). According to the results obtained, the greatest enzymatic activity of the culture was manifested mainly at 18 degrees, therefore, Figure 3 shows the general results revealed at this temperature. The levels of activities were very diverse among the yeasts, which might be evidence of varying biological activity of the cultures in question.

According to the results obtained, 4 cultures (1-32, 1-16.1, 1-16.2 and 3-39) have the most diverse enzyme complex (6 out of 7 studied exozymes were identified), culture 1-15 is inferior to them (5 exoenzymes),

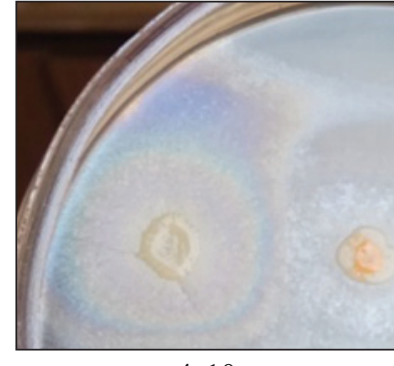

4-10

Figure 4. Opalescent zone examples (strains 4-10 and 7-71) at $18^{\circ} \mathrm{C}$ 


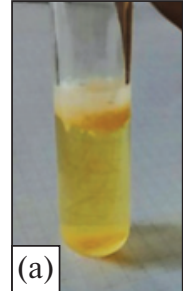

$2-2$

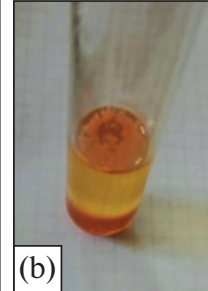

$7-71$

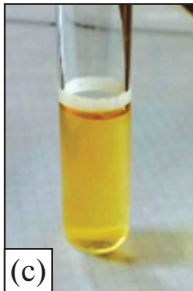

$1-16.2$

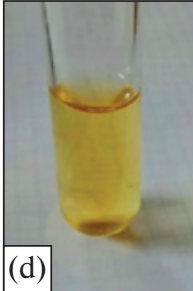

$4-11$

Figure 5. Yeast growth on liquid media: (a) - thick dense film at the border of air and liquid; (b) - uneven film at the border of air and liquid; (c) - ring-form growth; (d) - no growth

the rest of the isolates have only 2-4 exoenzymes. Common to all isolates of Antarctic yeast was the manifestation of lipolytic activity, while the most enzymatically active cultures were cultures 1-15, 1-32, and 7-71. A far fewer number of isolates was capable of proteolytic, cellulolytic, and pectolytic activities. Most isolates produced esters, some were able to secrete organic acids and make starch-like compounds.

Notably, there were opalescent zones around some colonies (mostly pink and red ones) in the lipolytic activity test (Fig. 4).

The nature of this phenomenon in yeasts has not been studied yet. But the fact of the discovery of such phenomenon, unusual for yeast cultures, attracts attention and increases interest for further study of the nature of this phenomenon.

In liquid media the yeasts cause opacification, sediment formation, appearance of rings or different kinds of film (Babyeva \& Golubev, 1979). Filmlike growth shows the cells' ability to unite in mycelial structures. Our studies showed that around half the isolates could produce films of various morphology on the surface of the liquid medium, some of the others grew as rings on the air/liquid border, and two isolates did not grow on the liquid medium. Figure 5 shows the results of growth in liquid medium of yeast cultures 2-2, 7-71, 1-16.2 and 4-11 as an example.

Table 3. List of strains studied and extracellular enzyme activities of yeasts and other features

\begin{tabular}{|c|c|c|c|c|c|c|c|c|c|c|c|}
\hline \multirow{3}{*}{ Cultures } & \multirow{2}{*}{\multicolumn{2}{|c|}{$\begin{array}{c}\text { lipolytic } \\
\text { Tween }\end{array}$}} & \multirow{3}{*}{$\begin{array}{c}\text { amylo- } \\
\text { lytic }\end{array}$} & \multirow{3}{*}{ DNAse } & \multirow{3}{*}{ urease } & \multirow{3}{*}{ proteolytic } & \multirow{3}{*}{ cellulolytic } & \multirow{3}{*}{ pectolytic } & \multirow{3}{*}{$\begin{array}{c}\text { organic } \\
\text { acids }\end{array}$} & \multirow{3}{*}{$\begin{array}{l}\text { starch-like } \\
\text { compounds }\end{array}$} & \multirow{3}{*}{ ethers } \\
\hline & & & & & & & & & & & \\
\hline & 20 & 80 & & & & & & & & & \\
\hline $1-15$ & + & + & + & + & - & + & - & + & - & + & - \\
\hline $1-32$ & + & + & + & + & + & + & - & + & - & - & - \\
\hline $1-16.1$ & + & + & + & + & + & + & + & - & - & - & + \\
\hline $1-16.2$ & + & + & + & + & + & + & + & - & - & - & + \\
\hline T3-1 & + & + & - & - & - & - & - & - & - & - & + \\
\hline $2-2$ & + & + & + & + & + & - & - & - & + & + & + \\
\hline $2-3$ & + & + & + & - & - & - & + & + & - & + & + \\
\hline $3-38$ & + & + & + & + & + & - & - & - & - & + & + \\
\hline $3-39$ & + & + & + & + & + & + & + & - & - & - & - \\
\hline $3-26$ & + & + & + & + & + & - & - & - & - & + & + \\
\hline 4-1 & + & + & + & + & + & - & - & - & - & + & + \\
\hline $4-6$ & + & + & - & + & - & - & - & - & - & - & - \\
\hline $4-7$ & + & + & + & + & + & - & - & - & - & + & + \\
\hline $4-8$ & + & + & - & + & - & - & - & - & - & - & - \\
\hline $4-9$ & + & + & + & + & + & - & - & - & - & - & + \\
\hline $4-10$ & + & + & + & + & - & - & - & - & - & - & + \\
\hline $4-11$ & + & + & + & + & - & - & - & - & - & - & + \\
\hline $7-71$ & + & + & + & + & + & - & - & - & - & + & + \\
\hline $7-180$ & + & + & - & + & - & - & - & - & - & - & + \\
\hline $8-36$ & + & + & + & + & - & - & - & - & + & - & - \\
\hline
\end{tabular}

Notes: "+" - the presence of activity in the investigated strain; "-" - lack of activity. 
Yeast's physiological state can be determined by the storage carbohydrates such as glycogen. The amount of glycogen in the cell changes depending on the yeast's age and culture conditions: in cells with low physiological activity it occupies less than a quarter of the space while in the mature ones - two-thirds and more. To qualitatively estimate the glycogen level in yeasts we stained them with the Lugol solution; 11 out of 20 tested cultures exhibited low glycogen storage capacity, eight others showed moderate capacity, and one culture had high glycogen storage capacity (Fig. 6). The isolates were studied using a $100 \times$ magnification of a light microscope and dark-colored intracellular inclusions were presumably attributed to glycogen grains.

"Carotenogenic yeasts" can be rich in lipids (up to $70 \% \mathrm{w} / \mathrm{w}$ ), which is why they are an object of research as an alternative source of lipids to use in biotechnology. Having studied this property at different stages of culture growth, we showed that most isolates after prolonged incubation began accumulating lipid drops reaching two thirds of the cell volume or more.

To find promising producers of biosurfactants of the glycolipid nature there were screened the yeasts which synthesize metabolites with emulsifying and wetting properties (Fedorova et al., 2010; Bueno et al., 2019; Gribanova \& Miamin, 2021b). We showed that a number of the tested cultures synthesized compounds with properties typical for glycolipids when grown on specialized media. The emulsification index for the cultural liquid showed that for 3 out of 20 cultures, the index exceeded $50 \%$, in seven others it was in the range of $20-50 \%$, and in ten more - below $20 \%$ (Fig. 7). When suspension drops were placed onto a hydrophobic surface it was found that they wetted it more than water did. The highest wetting ability was shown for five cultures. According to the literature (Bueno et al., 2019), the higher the emulsification index, the higher the microbes' destructive powers.

Natural utilization of hydrocarbons mixes has major outcomes for both biotechnology and ecology. One of hydrocarbon sources is mineral motor oil. The experiment on the yeasts' ability to destruct a layer of oil revealed eight isolates with high destructive activity (the cultures which were able to halve the volume of the added oil). Six more isolates were able

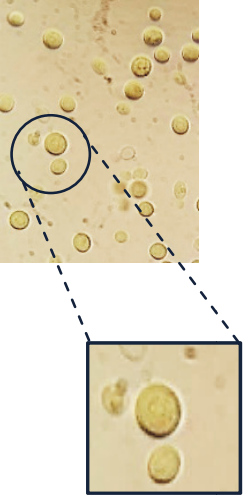

$2-2$

(no glycogen grains)

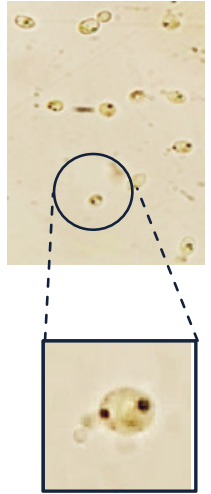

8-36

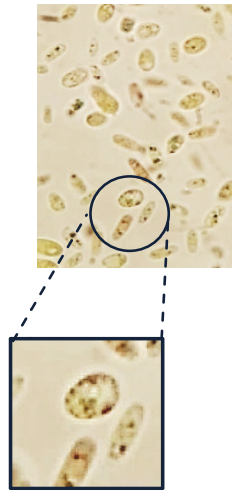

3-39

(3-7 grains)
Figure 6. Glycogen amount in cells of different yeast cultures (isolates 2-2, 8-36, and 3-39)

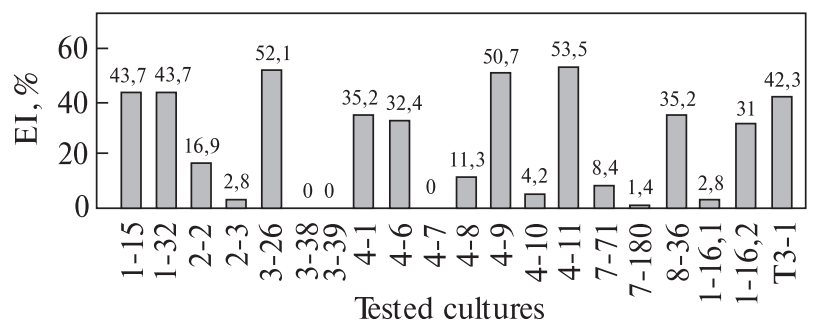

Figure 7. Results of calculations of the emulsification index of the studied yeast cultures
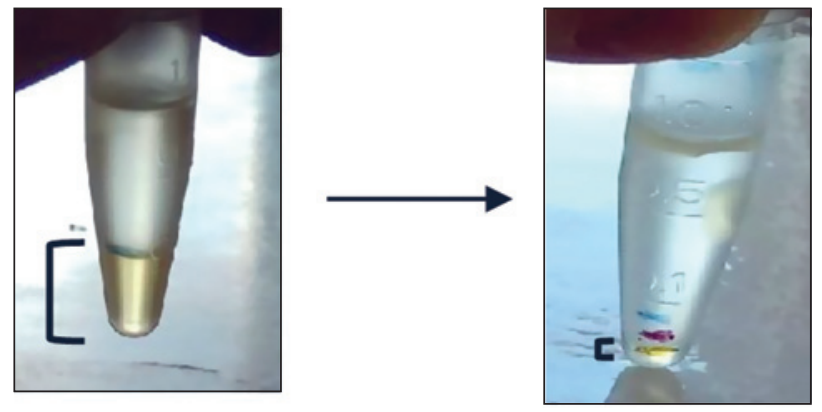

Figure 8. Efficiency of breaking down a layer of mineral motor oil (results for isolate 7-180)

to destroy less than a third of the oil, and four isolates either showed very little or no ability to do it.

Isolate 7-180 presented in Figure 8 destroyed the mineral motor oil layer by more than $2 / 3$ of the total oil volume (the original volume of oil (left image) and its remaining volume (right image) are shown graphically in square brackets). 


\section{Conclusions}

Thus, our work characterized 20 yeast isolates for which we studied a number of physiological and biochemical traits and the ability to produce biologically active substances. Among the cultures there were some promising for further study to use for biotechnology. In further work, the yeasts will be identified with the help of molecular-biological methods and the more interesting and promising species will be studied in more detail.

Note: in this article, mainly the qualitative characteristics of the isolated Antarctic yeast were presented. This stage of research is an integral part for further planning research work and providing more accurate quantitative characteristics of yeast cultures.

Author contributions: VM conceived the study. EG did the experiments. VM and EG analysed the results and wrote the manuscript.

Conflicts of Interest: No conflict of interest to declare.

\section{References}

Alcaíno, J., Cifuentes, V., \& Baeza, M. (2015). Physiological adaptations of yeasts living in cold environments and their potential applications. World Journal of Microbiology and Biotechnology, 31(10), 1467-1473. https://doi.org/10.1007/s11274015-1900-8

Babyeva, I. P., \& Golubev, V. I. (1979). Metody vydeleniya $i$ identifikacii drozhzhej [Methods for the isolation and identification of yeasts]. Pishhevaya promyshlennost.

Bagaeva, T. V., Ionova, N. E'., \& Nadeeva, G. V. (2013). Mikrobiologicheskaya remediaciya prirodnykh sistem ot tyazhelykh metalov [Microbiogical remediation of natural ecosystems from heavy metals]. Kazanskiy universitet.

Barahona, S., Yuivar, Y., Socias, G., Alcaíno, J., Cifuentes, V., \& Baeza, M. (2016). Identification and characterization of yeasts isolated from sedimentary rocks of Union Glacier at the Antarctica. Extremophiles, 20(4), 479-491. https://doi.org/10. 1007/s00792-016-0838-6

Bueno, J. L., Santos, P. A. D., da Silva, R. R., Moguel, I. S., Pessoa Jr, A., Vianna, M. V., Pagnocca, F. C., Sette, L. D., \& Gurpilhares, D. B. (2019). Biosurfactant production by yeasts from different types of soil of the South Shetland Islands (Maritime Antarctica). Journal of Applied Microbiology, 126(5), 1402-1413. https://doi.org/10.1111/jam.14206

Byrtusová, D., Shapaval, V., Holub, J., Šimanský, S., Rapta, M., Szotkowski, M., Kohler, A., \& Márová, I. (2020).
Revealing the potential of lipid and $\beta$-Glucans coproduction in Basidiomycetes yeast. Microorganisms, 8(7), 1034. https://doi. org/10.3390/microorganisms8071034

Cary, S. C., McDonald, I. R., Barrett, J. E., \& Cowan, D. A. (2010). On the rocks: the microbiology of Antarctic Dry Valley soils. Nature Reviews Microbiology, 8(2), 129-138. https://doi. org/10.1038/nrmicro2281

Connell, L. B., Redman, R., Rodriguez, R., Barrett, A., Iszard, M., \& Fonseca, A. (2010). Dioszegia antarctica sp. nov. and Dioszegia cryoxerica sp. nov., psychrophilic basidiomycetous yeasts from polar desert soils in Antarctica. International Journal of Systematic and Evolutionary Microbiology, 60(6), 1466-1472. https://doi.org/10.1099/ijs.0.015412-0

D’Amico, S., Collins, T., Marx, J.-C., Feller, G., Gerday, C., \& Gerday, C. (2006). Psychrophilic microorganisms: challenges for life. EMBO reports, 7(4), 385-389. https://doi.org/ 10.1038/sj.embor.7400662

Darling, C. A., \& Siple, P. A. (1941). Bacteria of Antarctica. Journal of Bacteriology, 42(1), 83-98.

De Pascale, D., De Santi, C., Fu, J., \& Landfald, B. (2012). The microbial diversity of Polar environments is a fertile ground for bioprospecting. Marine Genomics, 8, 15-22. https://doi.org/10.1016/j.margen.2012.04.004

Di Menna, M. E. (1960). Yeasts from Antarctica. Journal of General Microbiology, 23(2), 295-300. https://doi.org/10.1099/ 00221287-23-2-295

Di Menna, M. E. (1966). Yeasts in Antarctic soils. Antonie van Leeuwenhoek, 32(1), 29-38. https://doi.org/10.1007/BF 02097443

Fedorova, V. V., Petukhova, N. I., Khalimova, L. X., \& Zorin, V. V. (2010). Isledovanie usloviy sinteza biosurfaktantov mikroorganizmami [A study of conditions in which microbes produce biosurfactants]. Bashkir Chemical Journal, 17(5).

Gerday, C., Aittaleb, M., Bentahir, M., Chessa, J. P., Claverie, P., Collins, T., D’Amico, S., Dumont, J., Garsoux, G., Georlette, D., Hoyoux, A., Lonhienne, T., Meuwis, M.-A., \& Feller, G. (2000). Cold-adapted enzymes: from fundamentals to biotechnology. Trends in biotechnology, 18(3), 103-107. https://doi.org/10.1016/S0167-7799(99)01413-4

Gounot, A. M. (1986). Psychrophilic and psychrotrophic microorganisms. Experientia, 42(11), 1192-1197. https://doi.org/ 10.1007/BF01946390

Gribanova, E. A., \& Miamin, V. E. (2019, November $27-$ 29). Kharakteristika drozhzhej, vydelennykh iz razlichnykh ekosistem Vostochnoj Antarktidy [Description of yeasts isolated from various ecosystems of East Antarctica]. Materialy mezhdunarodnoj nauchno-prakticheskoj konferencii Biotekhnologii mikroorganizmov (pp. 321-325). Minsk, Belarus.

Gribanova, E. A., \& Miamin, V. E. (2021a). Fiziologo-bioximicheskaya xarakteristika drozhzhej, vydelennykh iz razlichnykh ekosistem Vostochnoy Antarktidy [Physiologo-biochemical characteristics of yeasts isolated from various ecosystems of the East Antarctica]. In Materialy' Mezhdunarod- 
nogo molodezhnogo nauchnogo foruma "Lomonosov-2021". MAKS Press.

Gribanova, E. A., \& Miamin, V. E. (2021b, May 11-13). Physiological and biochemical characteristics of yeasts isolated from different ecosystems of Eastern Antarctida [Conference Abstract]. X International Antarctic Conference Kyiv, Ukraine, 105-106. http://uac.gov.ua/international-cooperation/ mak/x-international-antarctic-conference-ua/

Gugliandolo, C., Michaud, L., Giudice, A. L., Lentini, V., Rochera, C., Camacho, A., \& Maugeri, T. L. (2016). Prokaryotic community in lacustrine sediments of Byers Peninsula (Livingston Island, Maritime Antarctica). Microbial Ecology, 71(2), 387-400. https://doi.org/10.1007/s00248-015-0666-8

Karpov, V. A. (1985). Metod opredeleniya DNK-aznoj aktivnosti [A method to determine the DNase activity]. Veterinariya, $11,79-80$.

Kurzanov, A. N. (1975). Metod opredeleniya lipoliticheskoj aktivnosti biologicheskikh zhidkostey [A method to determine the lipolytic activity of biological liquids]. Laboratornoe delo, $12,746-747$.

Lysak, V. V., \& Zheldakova, R. A. (2002). Mikrobiologiya: metodicheskie rekomendacii $k$ laboratornym zanyatiyam, kontrol samostoyatelnoy raboty studentov [Microbiology: methodical recommendations for laboratory assignments and control of the students' own work]. BSU. https://elib.bsu.by/handle/ $123456789 / 15743$

Roberts, G. D., Horstmeier, C. D., Land, G. A., \& Foxworth, J. H. (1978). Rapid urea broth test for yeasts. Journal of Clinical Microbiology, 7(6), 584-588. https://doi.org/10.1128/ jcm.7.6.584-588.1978

Robinson, C. H. (2001). Cold adaptation in Arctic and Antarctic fungi. New Phytologist, 151(2), 341-353. https:// doi.org/10.1046/j.1469-8137.2001.00177.x

Rukhlyadeva, A. P., \& Korchagina, G. T. (1973). Opredelenie pektoliticheskoy aktivnosti interferometricheskim me- todom [Determination of the pectolytic activity by interferometry]. Prikladnaya Biokhimiya i Mikrobiologiya, 6, 922927.

Sampaio, J. P. (1999). Utilization of low molecular weight aromatic compounds by heterobasidiomycetous yeasts: taxonomic implications. Canadian Journal of Microbiology, 45(6), 491-512. https://doi.org/10.1139/w99-020

Satyanarayana, T., \& Kunze, G. (Eds.). (2009). Yeast biotechnology: diversity and applications. Springer, Dordrecht. https:// doi.org/10.1007/978-1-4020-8292-4

Turkiewicz, M., Pazgier, M., Kalinowska, H., \& Bielecki, S. (2003). A cold-adapted extracellular serine proteinase of the yeast Leucosporidium antarcticum. Extremophiles, 7(6), 435442. https://doi.org/10.1007/s00792-003-0340-9

Villarreal, P., Carrasco, M., Barahona, S., Alcaíno, J., Cifuentes, V., \& Baeza, M. (2016). Tolerance to ultraviolet radiation of psychrotolerant yeasts and analysis of their carotenoid, mycosporine, and ergosterol content. Current Microbiology, 72(1), 94-101. https://doi.org/10.1007/s00284015-0928-1

Vishniac, H. S., \& Hempfling, W. P. (1979). Evidence of an indigenous microbiota (yeast) in the dry valleys of Antarctica. Journal of General Microbiology, 112(2), 301-314. https://doi. org/10.1099/00221287-112-2-301

Zenova, G. M., Stepanov, A. L., Lihacheva, A. A., \& Manucharova, N. A. (2002). Praktikum po biologii pochv [Soil biology handbook]. Izdatelstvo MGU.

Zubov, D. V., \& Tolchenov, A. A. (2012). Ekspress-metodika kontrolya aktivnosti fermentnogo kompleksa [Express method of monitoring the activity of an enzyme complex]. Vestnik Saratovskogo gosudarstvennogo texnicheskogo universiteta, 1(2), 64 .

Received: 9 November 2021 Accepted: 8 December 2021

\section{К. Грібанова ${ }^{1}$, В. Мямін ${ }^{1,2, ~ * ~}$}

${ }^{1}$ Білоруський державний університет, м. Мінськ, 220108, Білорусь

2 ДНВО «НПЦ НАН Білорусі з біоресурсів», м. Мінськ, 220072, Білорусь

* Автор для кореспонденції: vladmiamin@mail.ru

Фізіологічні та біохімічні властивості грунтових дріжджів з різних екосистем Східної Антарктиди

Реферат. Ряд дослідів з фізіології та біохімії були виконані для вивчення властивостей та біопотенціалу культур дріжджів, ізольованих із грунтів Східної Антарктиди. У статті наведено перелік вивчених морфологічних особливостей, а також описано результати вивчення ферментативних активностей та біохімічних характеристик цих культур. Антар- 
ктичні дріжджі, культивовані на агаризованих середовищах, мали широкий спектр ферментативних активностей: більшість проявляли ліполітичну, амілолітичну, ДНК-азну, уреазну активності та продукували ефіри, тоді як меншість була здатна також до протеолітичної, целюлолітичної та пектолітичної активностей, секреції органічних кислот та синтезу крохмалеподібних речовин. Вивчення стресостійкості ізолятів виявило стійкість до опромінення ультрафіолетовим світлом за довжиною хвилі 254 нм та до низьких концентрацій сульфату міді у середовищі. Якісна оцінка рівня глікогену, виявленого фарбуванням із застосуванням розчину Люголя, показала здатність культури накопичувати глікоген у значних кількостях. Також, встановлено здатність клітин дріжджів накопичувати ліпіди зі збільшенням віку культури. Руйнування поверхні мінеральної олії культуральним бульйоном уможливило визначення ізолятів дріжджів з високою руйнівною активністю. Отримані результати, зокрема різноманіття виявлених фізіологічних активностей, дозволяють вважати антарктичні дріжджі перспективними продуцентами біологічно активних сполук для використання у медицині та біотехнології.

Ключові слова: Антарктида, біосурфактанти, мікроорганізми, стресостійкість, ферментативні активності 